\title{
A changing Arctic Ocean
}

\author{
David N. Thomas (D), Damian L. Arévalo-Martínez (D), Kirsty C. Crocket (i),

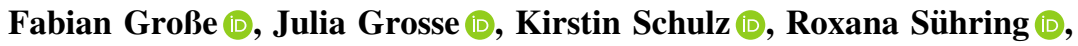 \\ Allyson Tessin (1)
}

Published online: 29 November 2021

\section{INTRODUCTION}

The Arctic is the fastest changing region on the planet. It is also intrinsically tied to global processes, whether they are climatic, environmental or socio-economic. The impacts of climate change on the vast and multiple interacting Arctic systems are inherently complex, although can be broadly summarised as an increase in temperature and the subsequent loss of sea-ice cover. This will ultimately result in the emergence of new physical and ecological states.

The rapidity with which the Arctic is reacting to global climate change is extraordinary. It is leading to scales of environmental change that society is unprepared for and is currently largely at a loss on how to manage or mitigate. We are witnessing a catastrophic restructuring of the ecology and biogeochemical processes traditionally used to define the rivers, lakes, ocean, glaciers, tundra and permafrost that collectively make up what we call the Arctic (Thomas 2021).

The science analysing Arctic environmental change is robust and unequivocal (IPCC 2019, 2021; AMAP 2021; Ingvaldsen et al. 2021; Steiner et al. 2021). As highlighted at the recent United Nations 26th Conference of the Parties in Glasgow, the undeniable scientific evidence of Arctic change is fundamental to the agenda driving the necessary swift political and societal change. There is also a clear understanding that what happens in the Arctic does not stay in the Arctic, but impacts the whole planet. This creates an even stronger challenge for funders and scientists to provide the necessary platforms for swift measurement of change and its reporting.

It is worth highlighting here a prediction by ICCI (2021) about Arctic Sea Ice that even with the fulfilment of "optimistic" nationally determined contributions (NDCs, i.e. $2.1{ }^{\circ} \mathrm{C}$ in 2100 and rising):
"Summer sea ice will disappear nearly every September starting at $1.7^{\circ} \mathrm{C}$ global warming, and the autumn freeze-up process will begin later. By the 2.2 ${ }^{\circ} \mathrm{C}$ peak, ice-free conditions will occur as early as June and persist well into November. This will greatly accelerate sea-level rise from melting of the Greenland ice sheet and Arctic glaciers, as well as carbon emissions from thawing permafrost. Today's Arctic ecosystem will be lost, with Arctic species replaced by those from the south as the Arctic Ocean becomes more like its southern counterparts."

This Special Issue addresses many of the effects of warming on the Arctic Ocean's ecosystems, driven principally by the cascade of ismpacts from the retreat and thinning of sea ice: e.g., release of chemical pollutants from melting sea ice; exposure of the ocean's surface to the atmosphere and the release of climatically-active trace gases; alteration of the balance of nutrient concentrations due to ocean circulation changes and the "Atlantification" of the Arctic Ocean; release of soil to the Arctic Ocean from permafrost thaw; the effect of seasonal ice retreat and thinning on biological productivity; the impact of changes in surface ocean productivity on the seafloor, including carbon sequestration in sediments; gauging the sensitivity of Arctic food webs to change, and their reliance on a single dominant species of zooplankton.

The contributions to this Special Issue have mostly originated from the Changing Arctic Ocean Programme (www.changing-arctic-ocean.ac.uk) that ran from 2017 to 2021, funded by the United Kingdom (NERC-Natural Environment Research Council) and Germany (BMBFFederal Ministry of Education and Research). The overarching goal of the 16 projects in the programme was to understand how change in the physical environment (ice 
and ocean) affects the large-scale ecosystem structure and biogeochemical functioning of the Arctic Ocean. Its key aims were (1) to identify and quantify the changes taking place in the Arctic Ocean's marine biology and biogeochemistry, and (2) to develop predictive models to gauge the impacts of these changes on ecosystem services now and in the future.

The observational datasets and their interpretation, the availability of new and refined numerical models for the Arctic Ocean, and their projections of future change, presented in this Special Issue will be valuable sources of scientific information for stakeholders involved in the Arctic and in global systems (both policy and science). Examples of fields for which the findings presented in this Special Issue will be of interest and relevance include: fisheries management, marine protected areas, climate research and forecasting, transport (shipping and defence industries), pollution hazards, resource exploitation and development and human health.

To start the special issue Huntington et al. (2022) provide a broad overview of the societal implications of a changing Arctic Ocean and how they will impact on indigenous communities and a wider global society. They outline the anticipated changes in the Arctic system and investigate the intertwined effects of regional environmental changes, the adaptation strategies of Indigenous Societies, and the increasing global importance of the Arctic for transportation, natural resource exploitation, military purposes and tourism. The article closes with an appeal to put our scientific knowledge and ability to predict environmental changes to use, and shape our societal response to a changing Arctic Ocean for the better.

Clearly there are new opportunities opening as well as geopolitical tensions developing. Food security and cultural continuity for Indigenous Peoples are endangered, or at best greatly disrupted. The need for inclusivity and respect of indigenous knowledge will be key for taking management agendas forward in the coming decades of rapid environment transition.

\section{ARCTIC OCEAN ECOSYSTEMS CHANGE}

The main biotic and abiotic factors which drive the extent and spatial variability of light under ice are discussed by Castellani et al. (2022), who also used model simulations to evaluate the effects of available light on the seasonal variability of primary production. Moreover, the authors discuss potential consequences of future changes in underice light for a wide range of marine ecosystems within the framework of ongoing climate change.

Changing light regimes clearly impact Arctic sea ice microbial assemblages. Campbell et al. (2022) highlight the best practices for documenting sea ice microbial communities and how they are being impacted by climate change. In particular, they emphasise the potential for studies that use molecular tools, optical and photometric approaches, and model simulations to address the challenges of investigating Arctic microbial communities in order to create an accurate understanding of the current conditions, which provides a baseline for future change.

The importance and challenges of Arctic zooplankton for the Arctic marine food web in a changing Arctic Ocean are discussed by Tarling et al. (2022). Specifically, insights into one of the main issues in the research into the calanoid copepod (genus Calanus) is the changing balance between true Arctic species and boreal Atlantic immigrants. The results indicate a shift towards boreal species taking over dominance from the Arctic species with implications for the Arctic food web as well as local fisheries. As the Calanus community becomes more influenced by boreal Atlantic species, their key Atlantic predators, such as commercially fished species capelin, Atlantic cod and haddock, become increasingly drawn to Arctic regions to feed. They discuss the sensitivity of Arctic habitats such as the Fram Strait to rapid environmental change and provides a glimpse into the consequences of environmental changes likely to take place elsewhere if the current rate of atmospheric emissions continues.

Bonnet-Lebrun et al. (2022) evaluated the role of sea surface temperature and inter-specific competition in the population and foraging ecology of guillemots. They concluded that while the abundances of Arctic Brünnich's guillemots declined under increased sea surface temperatures, competition with temperate common guillemots did not affect those abundances. Nevertheless, due to their similar foraging ecology, competition between both species could occur if food and space become limited, which in turn might be fostered by ongoing ocean warming in the region.

\section{ARCTIC OCEAN BIOGEOCHEMICAL CHANGE}

By combining datasets collected in the Barents Sea during the CAO programme with historical datasets, Tuerena et al. (2022) elucidated potential changes in nitrate and phosphate concentrations in response to changes in their supply and turnover. They concluded that the observed decreases in the upper ocean nutrient inventories in the Barents Sea are primarily driven by enhanced primary production as a result of weakened ocean stratification and increased light availability due to sea ice loss. In contrast, benthic-pelagic coupling in shallow shelf areas only plays a minor role in the nutrient budgets but has the potential to gain importance in the future if primary production continues to 
increase, potentially resulting in a substantial increase in sedimentation of organic matter.

März et al. (2022) investigated the consequences of changing Arctic Ocean processes for the benthic communities and biogeochemical processes in sediments. They report on the implications of future scenarios for carbon and nutrient dynamics in sediments and bottom waters and the possible impact of future industrial activity trying to exploit resources in previously ice-protected regions.

Buchanan et al. (2022) studied past and future changes in nitrogen stable isotopes $\left(\delta^{15} \mathrm{~N}\right)$ in the Arctic Ocean using a three-dimensional, coupled physical-biogeochemical model. They find that the canonical isotopic gradient of 2-3\% between the Pacific and Atlantic sectors of the Arctic Ocean has grown to $3-4 \%$ in recent decades and will further increase through the twenty-first century under a high emissions climate change scenario. This trend will complicate longitudinal food web studies using $\delta^{15} \mathrm{~N}$ as observed changes in $\delta^{15} \mathrm{~N}$ bulk tissue may not be easily attributed to changes in the $\delta^{15} \mathrm{~N}$ baseline or a species' trophic position.

The contemporary and future role for the Arctic Ocean and its exchange with the atmosphere of greenhouse gases nitrous oxide $\left(\mathrm{N}_{2} \mathrm{O}\right)$ and methane $\left(\mathrm{CH}_{4}\right)$ is discussed by Rees et al. (2022). The authors conclude that while estimates of the global marine source of $\mathrm{N}_{2} \mathrm{O}$ and $\mathrm{CH}_{4}$ to the atmosphere have significantly improved, a mechanistic understanding of the causes for the observed variability in sink-source dynamics and sea/ice-air gradients in the Arctic Ocean is still missing. They call for improved observational capabilities in the Arctic Ocean in order to reduce current emission estimates and strengthen the projections of future greenhouse gas emission trends within the context of global coupled models.

Campen et al. (2022) summarise the current understanding of dimethyl sulphide (DMS) and carbon monoxide (CO) sources and cycling in the Arctic. They demonstrate the interdependency and complexity of the ongoing changes in biogeochemical processes, and points to a potential increase of DMS and $\mathrm{CO}$ production with increasing ice melting, increasing light availability and shifting of phytoplankton communities due to climate change. The authors recommend that policymakers should create a framework for both adequate research efforts and sociopolitical measures needed to sustain the sensitive Arctic Ocean ecosystem, given its pronounced role for the global climate system and the well-being of the Arctic's human communities.

\section{LAND-OCEAN CONNECTIVITY CHANGE IN THE ARCTIC}

Considering the connections between land and ocean, Sanders et al. (2022) estimate the nitrogen load from the Lena River to the Laptev Sea using river measurements and incubations of delta soils to investigate the potential for reactive nitrogen release. They illustrate that the Lena River and delta act as a significant source of nitrogen to the coastal Arctic Ocean. Further, they suggest that the increased availability of inorganic nitrogen could result in increased nitrous oxide emissions.

Continuing on the theme of land-ocean connection, Mann et al. (2022) combine riverine organic carbon degradation rates from the Kolyma River and discharge measurements from the Kolyma and Lena Rivers with permafrost degradation experiments to investigate how carbon turnover rates may change in the future. They illustrate that permafrost-derived organic carbon significantly enhances aquatic carbon degradation rates and their results highlight that nearshore Arctic regions are likely to be particular hotspots for environmental change.

\section{ARCTIC OCEAN FOODWEB CHANGE AND FUTURE MANAGEMENT}

Changes in seasonal ice cover is transforming the seasonal primary production in the Barents Sea, and the balance between species throughout the entire foodweb is changing rapidly. Heath et al. (2022) discuss the likelihood of significant trends in productivity throughout the food web, including iconic Arctic fauna such as seabirds, cetaceans, pinnipeds and polar bears. They propose the case for adopting an Ecosystem Approach to Fisheries (EAF) in this region as part of a strategy to manage the impacts of climate change on high trophic levels.

Townhill et al. (2022) propose an integrated approach to better manage risks and reduce impacts to Arctic socioecological systems and promote sustainable use and conservation of Arctic resources. They use an example of pollutant exposure from maritime traffic in the Arctic to show that it is important to also consider the scale of changes from local, to regional and to an ecosystem scale. They emphasise the need for efforts to focus on balancing the ecological, economic and societal interests in the Arctic and the need to harmonise Arctic initiatives to ensure complementarity of specific policy measures and dedicated frameworks. 
Acknowledgements We thank the Natural Environment Research Council (NERC) and the German Ministry of Education and Research (BMBF) for funding the Changing Arctic Ocean Programme (2015-2021), including the funding for the open access to this special issue.

\section{REFERENCES}

AMAP. 2021. Arctic climate change update 2021: Key trends and impacts. Summary for policy-makers. Arctic Monitoring and Assessment Programme (AMAP), Troms $\varnothing$, Norway. 16 pp.

Bonnet-Lebrun, A.-S., T. Larsen, T.L. Thórarinsson, Y. Kolbeinsson, M. Frederiksen, T.I. Morley, D. Fox, A. Boutet, et al. 2022. Cold comfort: Arctic seabirds find refugia from climate change and potential competition in marginal ice zones and fjords. Ambio. https://doi.org/10.1007/s13280-021-01650-7.

Buchanan, P.J., A. Tagliabue, C. de la Vega, and C. Mahaffey. 2022. Oceanographic and biogeochemical drivers cause divergent trends in the nitrogen isoscape in a changing Arctic Ocean. Ambio. https://doi.org/10.1007/s13280-021-01635-6.

Campbell, K., I. Matero, C. Bellas, T. Turpin-Jelfs, P. Anhaus, M. Graeve, F. Fripiat, M. Tranter, et al. 2022. Monitoring a changing Arctic: Recent advancements in the study of sea ice microbial communities. Ambio. https://doi.org/10.1007/s13280021-01658-z.

Campen, H.I., D.L. Arévalo-Martínez, Y. Artioli, I.J. Brown, V. Kitidis, G. Lessin, A.P. Rees, and H.W. Bange. 2022. The role of a changing Arctic Ocean and climate for the biogeochemical cycling of dimethyl sulphide and carbon monoxide. Ambio. https://doi.org/10.1007/s13280-021-01612-z.

Castellani, G., G. Veyssière, M. Karcher, J. Stroeve, S.N. Banas, A.H. Bouman, A.S. Brierly, and S. Connan. 2022. Shine a light: Under-ice light and its ecological implications in a changing Arctic Ocean. Ambio. https://doi.org/10.1007/s13280-02101662-3.

Heath, M.R., D. Benkort, A.S. Brierley, U. Daewel, J.H. Laverick, R. Proud, and D.C. Speirs. 2022. Ecosystem approach to harvesting in the Arctic: Walking the tightrope between exploitation and conservation in the Barents Sea. Ambio. https://doi.org/10.1007/ s13280-021-01616-9.

Huntington, H.P., A. Zagorsky, B.P. Kaltenborn, H.C. Shin, J. Dawson, M. Lukin, P.E. Dahl, P. Guo, et al. 2022. Societal implications of a changing Arctic Ocean. Ambio. https://doi.org/ 10.1007/s13280-021-01601-2.

ICCI. 2021. State of the cryosphere 2021-a needed decade of urgent action. https://www.iccinet.org/statecryo21.

Ingvaldsen, R.B., K.M. Assmann, R. Primicerio, M. Fossheim, I.V. Polyakov, and A.V. Dolgov. 2021. Physical manifestations and ecological implications of Arctic Atlantification. Nature Review Earth \& Environment. https://doi.org/10.1038/s43017-02100228-x.

IPCC. 2019. IPCC Special Report on the Ocean and Cryosphere in a Changing Climate, eds. H.-O. Pörtner, D.C. Roberts, V. MassonDelmotte, P. Zhai, M. Tignor, E. Poloczanska, K. Mintenbeck, A. Alegría, et al. https://www.ipcc.ch/srocc/.

IPCC. 2021. Climate change 2021: The physical science basis. Contribution of Working Group 1 to the Sixth Assessment report of the Intergovernmental Panel on Climate Change, eds. V. Masson-Delmotte, P. Zhai, A. Pirani, S.L. Connors, C. Péan, S. Berger, N. Caud, Y. Chen, et al. Cambridge University Press. In Press.

Mann, P.J., J. Strauss, J. Palmtag, K. Dowdy, O. Ogneva, M. Fuchs, M. Bedington, R. Torres, et al. 2022. Degrading permafrost river catchments and their impact on Arctic Ocean nearshore processes. Ambio. https://doi.org/10.1007/s13280-021-01666-z.

März, C., F.S. Freitas, J.C. Faust, J.A. Godbold, S.F. Henley, A.C. Tessin, G.D. Abbott, R. Airs, et al. 2022. Biogeochemical consequences of a changing Arctic shelf seafloor ecosystem. Ambio. https://doi.org/10.1007/s13280-021-01638-3.

Rees, A.P., H.W. Bange, D.L. Arévalo-Martínez, Y. Artiolo, D.M. Ashby, I. Brown, H.I. Campen, D.R. Clark, et al. 2022. Nitrous oxide and methane in a changing Arctic Ocean. Ambio. https:// doi.org/10.1007/s13280-021-01633-8.

Sanders, T., C. Fiencke, M. Fuchs, C. Haugk, B. Juhls, G. Mollenhauer, O. Ogneva, P. Overduin, et al. 2022. Seasonal nitrogen fluxes of the Lena River Delta. Ambio. https://doi.org/ 10.1007/s13280-021-01665-0

Steiner, N., J. Bowman, K. Campbell, M. Chierici, E. EronenRasimus, M. Falardeau, H. Flores, A. Fransson, et al. 2021. Climate change impacts on sea-ice ecosystems and associated ecosystem services. Elementa Science of the Anthropocene 9 (1): 00007. https://doi.org/10.1525/elementa.2021.00007.

Tarling, G.A., J.J. Freer, N.S. Banas, A. Belcher, M. Blackwell, C. Castellani, K.B. Cook, F.R. Cottier, et al. 2022. Can a key boreal Calanus copepod species now complete its life-cycle in the Arctic? Evidence and implications for Arctic food-webs. Ambio. https://doi.org/10.1007/s13280-021-01667-y.

Thomas, D.N., ed. 2021. Arctic ecology, 443. Oxford: WileyBlackwell.

Townhill, B.L., E. Reppes-Chrysovitsinos, R. Sühring, C.J. Halsall, E. Mengo, T. Sanders, K. Dähnke, O. Crabeck, et al. 2022. Pollution in the Arctic Ocean: An overview of multiple pressures and implications for ecosystem services. Ambio. https://doi.org/ 10.1007/s13280-021-01657-0.

Tuerena, R.E., C. Mahaffey, S.F. Henley, C. de la Vega, L. Norman, T. Brand, T. Sanders, M. Debyser, et al. 2022. Nutrient pathways and their susceptibility to past and future change in the Eurasian Arctic Ocean. Ambio. https://doi.org/10.1007/s13280-02101673-0.

Publisher's Note Springer Nature remains neutral with regard to jurisdictional claims in published maps and institutional affiliations.

\section{AUTHOR BIOGRAPHIES}

David N. Thomas $(\square)$ is the Professor of Arctic Ecosystems Research at the University of Helsinki, Finland.

Address: University of Helsinki, Viikinkaari 1, P.O. Box 65, 00014 Helsinki, Finland.

e-mail: david.thomas@helsinki.fi

Damian L. Arévalo-Martínez is a postdoctoral researcher at the Institute of Geosciences of Kiel University in Germany. Address: Kiel University, Otto-Hahn-Platz 1, 24118 Kiel, Germany. e-mail: darevalo@geomar.de

Kirsty C. Crocket co-ordinated the Changing Arctic Ocean programme until 2020 and is now an environmental scientist at the Dounreay nuclear site.

Address: Dounreay, Thurso KW14 7TZ, Caithness, UK.

e-mail: k.c.crocket@gmail.com

Fabian Große is a Research Scientist at the Federal Institute of Hydrology, Germany, and a Visiting Researcher at the Department of Mathematics and Statistics of the University of Strathclyde.

Address: Department of Microbiology, Federal Institute of Hydrology, Am Mainzer Tor 1, 56068 Koblenz, Germany.

e-mail: grosse@bafg.de 
Julia Grosse was a researcher at GEOMAR, Helmholtz Centre for Ocean Research Kiel, during most of the production of the special issue and is now a life coach and consultant.

Address: Coaching and Consulting, 01662 Meissen, Germany.

e-mail: Julia.grosse@yahoo.com

Kirstin Schulz is a Research Fellow at The Oden Institute for Computational Engineering and Sciences, The University of Texas at Austin, Austin, Texas, USA.

Address: 201 E. 24th Street, Stop C0200, Austin, TX 78712-1229,

USA.

e-mail: kiki.schulz@utexas.edu
Roxana Sühring is an Assistant Professor for Environmental Analytical Chemistry at the Department of Chemistry and Biology at Ryerson University in Toronto, Canada.

Address: Department of Chemistry and Biology, Ryerson University, Toronto, ON M5B 2K3, Canada.

e-mail: roxana.suehring@ryerson.ca

Allyson Tessin is an Assistant Professor at the Department of Geology at Kent State university in Ohio, USA.

Address: Department of Geology, Kent State University, 800 E Summit St, Kent, OH 44240, USA.

e-mail: atessin@kent.edu 